\title{
The influence of dietary fibre and environmental temperature on the development of the gastrointestinal tract, digestibility, degree of fermentation in the hind-gut and energy metabolism in pigs
}

\author{
BY HENRY JØRGENSEN*, XIN-QUAN ZHAO†, AND BJØRN O. EGGUM \\ National Institute of Animal Science, Department of Animal Physiology and Biochemistry, Research \\ Centre Foulum, PO Box 39, DK-8830 Tjele, Denmark
}

(Received 31 October 1994 - Revised 20 February 1995 - Accepted 31 May 1995)

The present study was undertaken to provide detailed information about the effect of dietary fibre (DF) level on the development of the digestive tract, on nutrient digestibility and on energy and protein metabolism of pigs housed in low $\left(13^{\circ}\right)$ or high $\left(23^{\circ}\right)$ thermal environments. Low- and high-fibre diets $(59$ v. $268 \mathrm{~g} \mathrm{DF} / \mathrm{kg} \mathrm{DM}$ ) were studied in three balance periods with fistulated pigs in the weight range $45-120 \mathrm{~kg}$. Heat production was measured using open-circuit respiration chambers. Pea fibre and pectin were used to adjust the DF level in the high-fibre diet. Per kg empty body weight the stomach, caecum and colon and the length of colon were significantly greater in pigs consuming the high-fibre diet than in those on the low-fibre diet. Pigs kept at low temperature had significantly heavier caecums than those kept at the high temperature. Digestibilities of protein, DM and energy were lowest for the high-fibre diet. Only minor amounts of NSP and its constituent sugars were degraded anterior to the ileum, whereas in the hind-gut the fermentation of the total NSP fraction was high, being 0.77 for the high-fibre diet and 0.59 for the low-fibre diet. Feeding the high-fibre diet increased the flow of digesta through the terminal ileum 5-6-fold and an extra $460 \mathrm{~g}$ organic matter was fermented daily in the hind-gut compared with pigs fed on the low-fibre diet. The amount of retained energy as a proportion of metabolizable energy decreased in relation to the amount of energy fermented in the hind-gut. Based on the present data it was estimated that the relative value of energy derived from hind-gut fermentation was 0.73 in comparison with energy enzymically digested in the small intestine. There was negligible effect of the temperature - fibre interaction on energy metabolism. However, it could be calculated that the decrease in temperature from $23^{\circ}$ to $13^{\circ}$ was associated with an increase in heat production by $2.9 \mathrm{MJ} / \mathrm{pig}$ per $\mathrm{d}$.

Gutfill: Heat increment: Non-starch polysaccharides: Fermentation

A general view is that high-fibre diets have a low energy density due to the low digestibility (e.g. Eggum et al. 1982, 1984; Just et al. 1983 b) and low net energy value of fibres digested (Eggum et al. 1982; Livesey, 1992). The end-products of the microbial degradation of dietary fibre (DF) are various gases $\left(\mathrm{H}_{2}, \mathrm{CO}_{2}, \mathrm{CH}_{4}\right)$, lactic acid and short-chain fatty acids (SCFA). The SCFA produced are rapidly absorbed from the gut lumen (Rechkemmer et al. 1988). Even in single-stomached animals such as rats and pigs these end-products can provide a substantial amount of energy (Argenzio \& Southworth, 1974; Eggum et al. 1984; Bach Knudsen et al. 1991).

DF also affects the length and weight of the gastrointestinal (GI) tract as well as the size of internal organs. Weights of liver, kidney and empty segments of the GI tract are increased relative to body weight by high-DF diets in both pigs and rats (Pond et al. 1988; Anugwa et al. 1989; Hansen et al. 1992; Zhao et al. 1995). There is also a strong indication

* For reprints.

$\dagger$ Present address: Northwest Plateau Institute of Biology, The Chinese Academy of Sciences, Xining, Qinghai, 810001 , China. 
that the differences in weights of visceral organs are highly related to differences in fasting heat production in animals due to different previous nutritional treatments (Koong et al. 1985; Ferrell \& Koong, 1986).

Because a larger part of the digestible energy (DE) of fibrous feedstuffs is lost as heat (heat increment) during the digestive and metabolic processes than from feedstuffs higher in starch or fat, the energy value of fibrous diets may be influenced by the thermal environment in which the animals are maintained (Stahly \& Cromwell, 1986). Changes in the thermal environment can influence feed intake, metabolism, nutrient requirements and efficiency of utilization (Dauncey \& Ingram, 1986; Close, 1989; Hoffmann et al. 1991). Both heat stress and cold stress increase energy expenditure and result in an increased requirement for maintenance. A higher requirement of energy for maintenance during cold exposure alters fat deposition to a greater extent than protein deposition, resulting in a leaner carcass (Zhao et al. 1995). A hot environment has a similar influence on carcass composition but this is due to a reduced feed intake (Verstegen et al. 1973; Stahly \& Cromwell, 1986).

The present study was undertaken to provide detailed information on the effects of dietary fibre on energy and protein metabolism in pigs housed in different thermal environments. The variables studied included, also, the effect of fibre on the development of the GI tract and on nutrient digestibility.

\section{MATERIALS AND METHODS}

\section{Experimental design}

The experiment was carried out using a factorial design that comprised two levels of DF, low fibre and high fibre, i.e. 59 and $268 \mathrm{~g} \mathrm{DF} / \mathrm{kg}$ diet DM respectively, and two environmental temperatures, low $\left(13^{\circ}\right)$ and high $\left(23^{\circ}\right)$. The relative humidity was set to 60 . Eight pigs in the weight range $45-120 \mathrm{~kg}$ were used during a study lasting 3 months and a balance period of 1 week was introduced for each pig every month.

After completion of the experiment the animals were killed by intravenous injection of sodium pentobarbital $4 \mathrm{~h}$ after the morning meal. The contents of the GI tract were removed and weighed and the weight of the digesta-free empty body (EBW) and GI tract of each pig was recorded.

\section{Housing}

The pigs were housed in two climatically controlled rooms, one for each allocated temperature. Each room had a volume of $43 \mathrm{~m}^{3}$ and contained four smooth-walled pens of $2.5 \mathrm{~m}^{2}$. To avoid using straw as bedding, half the floor was covered with raised plastic grating where the pig could lie down comfortably. The climate in the rooms could be kept constant in any range between 5 and $35^{\circ}$, with a relative humidity between 50 and 80 in the temperature range $18-35^{\circ}$ and between 60 and 90 in the temperature range $5-18^{\circ}$, by passing air over cooling and heating surfaces. The air in the rooms was changed about eighteen times $/ \mathrm{h}$ but air speed at the pig level was below $0.2 \mathrm{~m} / \mathrm{s}$. The amount of air being re-circulated could be adjusted from 0 to $100 \%$.

Heat production was estimated from calculations of gas exchange using two open-circuit respiration chambers. Each respiration chamber is built of stainless steel plates welded airtightly together. The floor area is $5.1 \mathrm{~m}^{2}(2.83 \times 1.79 \mathrm{~m})$ and the volume $11.2 \mathrm{~m}^{3}$. A false ceiling built of perforated ( $3 \mathrm{~mm}$ diameter) stainless steel sheeting is placed $140 \mathrm{~mm}$ below the ceiling in the chamber. The in-coming atmospheric air is mixed with the recirculated air before the cooling and heating surfaces and enters the chamber over the false ceiling where it mixes with the chamber air without causing draught (air speed below $0 \cdot 1 \mathrm{~m} / \mathrm{s}$ ). The climate in the respiration chambers can be kept constant in any range between 0 and $40^{\circ}$ and the relative humidity from 40 to 80 . To obtain thorough mixing of the air in the 
chambers the internal ventilation changes the air in the chambers up to 80 times $/ \mathrm{h}$. In the present study the volume of the outgoing air from the two chambers was measured continuously from the differential pressure over both sides of an orifice (Hartmann \& Braun, Frankfurt, Germany) and converted to standard temperature and pressure for dry air. A paramagnetic $\mathrm{O}_{2}$ analyser (Magnos 4G, Hartmann \& Braun) and two infra-red analysers for measuring $\mathrm{CO}_{2}$ and $\mathrm{CH}_{4}$ (Uras 3, Hartmann \& Braun) were used to measure the concentrations of $\mathrm{O}_{2}, \mathrm{CO}_{2}$ and $\mathrm{CH}_{4}$ in aliquot samples of the out-going and in-coming air. The concentrations of $\mathrm{O}_{2}, \mathrm{CO}_{2}$ and $\mathrm{CH}_{4}$, temperature, relative humidity and rate of flow from each chamber were recorded automatically on-line every second minute, from which the composition of the gas from each chamber was measured fifteen times per $h$. Both in the climatically controlled rooms and the respiration chambers a $12 \mathrm{~h}$ (06.00-18.00 hours) light-dark cycle was operated.

\section{Animals}

Eight barrows from two litters with an average weight of $20 \mathrm{~kg}$ were obtained from the National Institute of Animal Science (Foulum, Denmark) swine herd. The pigs were adapted to the environmental temperatures and tested for tolerance of DF levels to obtain information on the maximal inclusion rate of fibre and to estimate the metabolizabe energy (ME) content of the diets in order to feed the pigs on the two diets the same daily amount of ME. At an average weight of $37 \mathrm{~kg}$ each pig was fitted with a simple T-cannula at the distal ileum approximately $150 \mathrm{~mm}$ anterior to the ileal-caecal junction. The pigs were allowed 2 weeks of recovery after surgery before initiating the balance study.

\section{Diets and feeding}

The added fibre sources were pea fibre (Nutrio P-Fibre $150 \mathrm{C}$ provided by Danisco, Brabrand, Denmark) (106 g protein, $447 \mathrm{~g} \mathrm{DF}$ and $318 \mathrm{~g}$ starch $/ \mathrm{kg} \mathrm{DM}$ ) and pectin (Mexpectin, Grindsted Products, Brabrand, Denmark), both rich in soluble DF. The diets were formulated to supply equal amounts of digestible protein and fat per unit ME. Consequently the chemical compositions of the low- and high-fibre diets differed. When the pigs weighed about $80 \mathrm{~kg}$ the protein concentration was reduced by replacing fishmeal and casein with barley. The average compositions of the low- and high-fibre diets are shown in Table 1.

\section{Experimental procedure}

The animals were fed three times daily at $07.00,15.00$ and 23.00 hours with the two diets both adjusted to give the same amount of ME per $d$ with an increase of $0.28 \mathrm{MJ} M E / d$. Two pigs at a time, one from each environmental temperature, were on balance throughout the experiment. During the collection and balance periods the pigs were kept in stainless steel metabolism cages in the respiration chambers. Ileal digesta was sampled for a total of $8 \mathrm{~h}$ on $2 \mathrm{~d}$ : on day 1 from $09.00-11.00$ and $13.00-15.00$ hours; on day $207.00-09.00$ and 11.00-13.00 hours. Gas exchange and heat production were measured for $48 \mathrm{~h}$ on days 3 and 4 . Faeces and urine were collected quantitatively during the last $4 \mathrm{~d}$ in each collection period.

\section{Analytical methods}

$\mathrm{Cr}_{2} \mathrm{O}_{3}$ and organic acid determinations were performed on wet materials. All other analyses were carried out on freeze-dried materials except for the diets which were analysed on an air-dry basis. DM contents of feed, ileal digesta and faeces were determined by oven-drying at $105^{\circ}$ for $20 \mathrm{~h}$. All the following analyses were made in duplicate: protein $(\mathrm{N} \times 6.25)$ by a modified Kjeldahl method (KjellFoss 16200 Autoanalyser; Foss Electric A/S, Hillerød, Denmark) and energy by bomb calorimetry (IKA-C 400; Janke \& Kunthel, KG IKA- 
Table 1. Dietary ingredients and chemical composition of the experimental diets

\begin{tabular}{|c|c|c|}
\hline Fibre level... & Low & High \\
\hline $\begin{array}{l}\text { Ingredients }(\mathrm{g} / \mathrm{kg}) \\
\text { Pea fibre source } \\
\text { Pectin } \\
\text { Barley } \\
\text { Wheat starch } \\
\text { Fish meal } \\
\text { Casein } \\
\text { Soyabean oil } \\
\text { Dicalcium phosphate } \\
\text { Monocalcium phosphate } \\
\text { Calcium carbonate } \\
\text { NaCl } \\
\text { Mineral-vitamin mixture* } \\
\text { Chromic oxide (marker) }\end{array}$ & $\begin{array}{r}- \\
246 \\
572 \\
84 \\
36 \\
30 \\
10 \\
15 \\
-3 \\
2 \\
2\end{array}$ & $\begin{array}{r}350 \\
25 \\
516 \\
- \\
38 \\
16 \\
30 \\
15 \\
3 \\
3 \\
2 \\
2\end{array}$ \\
\hline $\begin{array}{l}\text { Chemical composition }(\mathrm{g} / \mathrm{kg} \text { D } \\
\text { Protein }(\mathrm{N} \times 6.25) \\
\text { HCl-fat } \\
\text { Starch } \\
\text { S-NSP } \\
\text { I-NSP } \\
\text { NSP } \\
\text { Klason lignin } \\
\text { Dietary fibre } \\
\text { Ash } \\
\text { Gross energy }(\mathrm{MJ} / \mathrm{kg} \mathrm{DM})\end{array}$ & $\begin{array}{c}143 \\
58 \\
696 \\
9 \\
43 \\
52 \\
7 \\
59 \\
45 \\
18 \cdot 60\end{array}$ & $\begin{array}{c}161 \\
62 \\
435 \\
93 \\
163 \\
256 \\
12 \\
268 \\
46 \\
18.94\end{array}$ \\
\hline $\begin{array}{l}\text { Constituent sugars of the NSP } \\
\text { Rhamnose } \\
\text { Arabinose } \\
\text { Xylose } \\
\text { Mannose } \\
\text { Galactose } \\
\text { Glucose } \\
\text { Uronic acids }\end{array}$ & $\begin{array}{r}\text { tr } \\
6.5 \\
12 \cdot 0 \\
1.7 \\
1.3 \\
30 \cdot 2 \\
0.8\end{array}$ & $\begin{array}{r}2.8 \\
87.7 \\
35 \cdot 7 \\
2.7 \\
15 \cdot 4 \\
86.5 \\
21.9\end{array}$ \\
\hline
\end{tabular}

HCl-fat, hydrochloric acid-fat; S-NSP, soluble non-starch polysaccharides; I-NSP, insoluble non-starch polysaccharides; $\operatorname{tr}$, trace.

* Supplied (/kg diet): retinol acetate $1376 \mu \mathrm{g}$, cholecalciferol $25 \mu \mathrm{g}$, DL- $\alpha$-tocopherol acetate $50 \mathrm{mg}$, menadione $2 \mathrm{mg}$, riboflavin $4 \mathrm{mg}$, D-pantothenic acid $10 \mathrm{mg}$, cyanocobalamin $0.02 \mathrm{mg}, \mathrm{FeSO}_{4} .7 \mathrm{H}_{2} \mathrm{O} 250 \mathrm{mg}, \mathrm{ZnO} 100 \mathrm{mg}$, $\mathrm{Mn}_{3} \mathrm{O}_{4} 36 \mathrm{mg}, \mathrm{CuSO}_{4} .5 \mathrm{H}_{2} \mathrm{O} 80 \mathrm{mg}, \mathrm{KI} 260 \mu \mathrm{g}, \mathrm{Na}_{2} \mathrm{SeO}_{3} 660 \mu \mathrm{g}$.

Werk, Heitersheim, Germany). Ash was analysed according to the method of the Association of Official Analytical Chemists (1975) while fat was extracted with diethyl ether after acid hydrolysis (Stoldt, 1952). $\mathrm{Cr}_{2} \mathrm{O}_{3}$ was determined using the method of Schürch et al. (1950). C was measured as described by Neergaard et al. (1969). Starch was analysed by the enzymic method reported by Bach Knudsen et al. (1993). Total NSP and their constituent sugars were determined using a modification of the methods of Theander \& Åman (1979), Theander \& Westerlund (1986) and Englyst et al. (1982) as described by Bach Knudsen et al. (1993). Klason lignin in the diets was determined gravimetrically as the

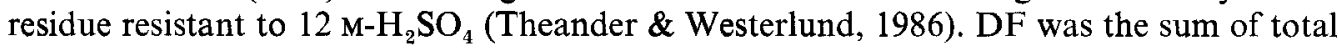
NSP and Klason lignin.

Total lactic acid (D- and L-isomers) was measured by specific enzymes in a coupled enzymic reaction with $\mathrm{NAD}^{+}$. Total SCFA were estimated by GLC as described by Fussell \& McCalley (1987). 


\section{Calculations and statistical analyses}

$\mathrm{ME}$ includes energy losses from both urine and $\mathrm{CH}_{4}$. The average daily heat production was calculated according to Brouwer (1965). Both the respiratory quotient and $\mathrm{C}-\mathrm{N}$ balance methods were used to calculate heat production (Christensen et al. 1988). All calculations of gas exchange were carried out on the average of the two $24 \mathrm{~h}$ respiration measurements. ANOVA was done using the general linear models procedure (Statistical Analysis Systems, 1985), with the effects of fibre, temperature and interactions between fibre and temperature as main effects and adjusting for the period effect. When no significant interaction between fibre and temperature was found, as in most cases, the results in the tables were presented as main effects. When significant effects were obtained, differences between means were compared by Fisher's least significant difference procedure (Milliken \& Johnson, 1984).

\section{RESULTS}

\section{Body weight and length and weight of gastrointestinal tract}

The health of the pigs was good throughout the study. Compared with pigs on the low-fibre diet the animals on the high-fibre diet had a higher final weight (Table 2) and a higher daily gain $(849 v .763 \mathrm{~g} / \mathrm{d})$ but with a higher gutfill $(82 v .29 \mathrm{~g} / \mathrm{kg}$ body weight). After correcting the body weight for gutfill there was no difference between the two types of diet in the final weight or in daily gain. The environmental temperature did not have any influence on gutfill but affected the weight gain $\left(13^{\circ}: 669\right.$ and $23^{\circ}: 837 \mathrm{~g}$ empty body gain/d).

Per kg empty-body weight (EBW) the weights of stomach, caecum and colon and the length of the colon were significantly $(P<0.05)$ greater in pigs consuming the high-fibre diet than in pigs fed on the low-fibre diet. This increase was nearly twofold for caecum and colon and the length also increased considerably. The GI tract was also influenced by environmental temperature. Pigs kept at low temperature had heavier caecums and significantly longer small intestines (per $\mathrm{kg} \mathrm{EBW}$ ) than those kept at the higher temperature.

\section{Digestibility}

Ileal and faecal digestibilities of organic matter, protein and energy followed in general the same pattern, being negatively related to the intake of DF (Table 3 ). The high-fibre diet resulted in a significantly lower digestibility at the terminal ileum than the low-fibre diet. The digestibilities at the ileal level were, for high- and low-fibre diets respectively: organic matter $0.58,0.89$; protein $0.64,0.76$; energy $0.58,0.89$. When measured at the faecal level the digestibilities of the three constituents for the low- and high-fibre diets respectively were: organic matter $0.85,0.95$; protein $0.74,0.92$; energy $0.82,0.94$. The low environmental temperature decreased digestibility slightly at the terminal ileum but the effect was significant only for starch.

Starch was almost completely digested at the end of the small intestine although there was a lower digestibility of starch for the high-fibre diet (0.95). The digestibility of NSP was very low at the terminal ileum and not significantly different between the two diets. The digestion of the constituent sugars of the NSP fraction at this site of the GI tract (Table 4) was low but very variable with values ranging from 0.34 to -0.68 . The digestion of NSP in the hind-gut was significantly higher for the high-fibre diet $(0.77)$ than for the low-fibre diet $(0 \cdot 59)$.

\section{Flow of nutrients at the terminal ileum and at faeces level}

The flows of wet and dry materials at the terminal ileum were mainly determined by the DF intake and were estimated to be 2.80 and $15.30 \mathrm{~kg}$ wet material/d corresponding to 270 and $1073 \mathrm{~g} \mathrm{DM} / \mathrm{d}$ for the low- and high-fibre diets, respectively (Table 5). The ileal digesta from pigs fed on the high-fibre diet contained significantly less DM $(0.072 \mathrm{~g} / \mathrm{kg})$ than digesta from 
Table 2. Effect of dietary fibre and environmental temperature on final body weight, gutfill and weight and length of the digestive tract in pigs*

(Mean values for four pigs)

\begin{tabular}{|c|c|c|c|c|c|}
\hline & \multicolumn{2}{|c|}{ Dietary fibre } & \multicolumn{2}{|c|}{ Temperature } & \multirow[b]{2}{*}{ RMSE } \\
\hline & Low & High & $13^{\circ}$ & $23^{\circ}$ & \\
\hline Body wt (BW) $(\mathrm{kg})$ & 122 & 129 & $117^{\mathrm{a}}$ & $134^{b}$ & 6 \\
\hline Gutfill (g/kg BW) & $29^{a}$ & $82^{\mathrm{b}}$ & 52 & 60 & 14 \\
\hline Empty-body wt (EBW) (kg) & 118 & 119 & $111^{\mathrm{a}}$ & $126^{b}$ & 5 \\
\hline \multicolumn{6}{|l|}{ GI tract wt (g/kg EBW) } \\
\hline Stomach & $5 \cdot 74^{\mathrm{a}}$ & $7 \cdot 27^{b}$ & $6 \cdot 40$ & $6 \cdot 61$ & 0.72 \\
\hline Small intestine & $15 \cdot 57$ & $16 \cdot 23$ & 16.67 & $15 \cdot 14$ & $1 \cdot 33$ \\
\hline Caecum & $1 \cdot 64^{a}$ & $2 \cdot 83^{\mathrm{b}}$ & $2 \cdot 45^{\mathrm{a}}$ & $2 \cdot 02^{\mathrm{b}}$ & 0.14 \\
\hline Colon & $8 \cdot 70^{\mathrm{a}}$ & $17 \cdot 23^{\mathrm{b}}$ & 13.00 & $12 \cdot 93$ & 0.83 \\
\hline Total GI tract & $31 \cdot 65^{\mathrm{a}}$ & $43 \cdot 56^{\mathrm{b}}$ & $38 \cdot 51$ & $36 \cdot 70$ & $1 \cdot 51$ \\
\hline \multicolumn{6}{|l|}{ GI tract length (m/kg EBW) } \\
\hline Small intestine & $0 \cdot 151$ & 0.157 & $0 \cdot 163^{\mathrm{a}}$ & $0 \cdot 145^{\mathrm{b}}$ & 0.009 \\
\hline Large intestine & $0.047^{\mathrm{a}}$ & $0.061^{\mathrm{b}}$ & 0.057 & 0.051 & 0.005 \\
\hline
\end{tabular}

RMSE, root mean square error; gutfill, content of the digestive tract; GI, gastrointestinal.

$a, b$ Mean values within a row within a treatment with different superscript letters were significantly different $(P<0 \cdot 05)$.

* For details of diets and procedures, see Table 1 and pp. 366-367.

Table 3. Apparent ileal and faecal digestibilities in pigs fed on low-or high-fibre diets and kept at two environmental temperatures*

(Mean values for four pigs)

\begin{tabular}{|c|c|c|c|c|c|}
\hline & \multicolumn{2}{|c|}{ Dietary fibre } & \multicolumn{2}{|c|}{ Temperature } & \multirow[b]{2}{*}{ RMSE } \\
\hline & Low & High & $13^{\circ}$ & $23^{\circ}$ & \\
\hline \multicolumn{6}{|l|}{ Ileal digestibilities } \\
\hline Crude protein & $0.76^{\mathrm{a}}$ & $0.64^{b}$ & 0.68 & 0.72 & 0.04 \\
\hline Starch & $1 \cdot 00^{\mathrm{a}}$ & $0.95^{\mathrm{b}}$ & $0.97^{\mathrm{a}}$ & $0.98^{\mathrm{b}}$ & 0.01 \\
\hline NSP & 0.09 & $0 \cdot 01$ & 0.00 & 0.09 & $0 \cdot 23$ \\
\hline Organic matter & $0.89^{\mathrm{a}}$ & $0.58^{\mathrm{b}}$ & 0.72 & 0.75 & 0.04 \\
\hline Energy & $0.87^{\mathrm{a}}$ & $0.58^{b}$ & 0.71 & 0.74 & 0.04 \\
\hline \multicolumn{6}{|l|}{ Faecal digestibilities } \\
\hline Crude protein & $0.92^{\mathrm{a}}$ & $0.74^{\mathrm{b}}$ & 0.83 & 0.83 & 0.02 \\
\hline Starch & 1.00 & 1.00 & 1.00 & $1 \cdot 00$ & - \\
\hline NSP & $0.59^{\mathrm{a}}$ & $0.77^{\mathrm{b}}$ & 0.70 & 0.66 & 0.07 \\
\hline Organic matter & $0.95^{\mathrm{a}}$ & $0.85^{\mathrm{b}}$ & 0.90 & 0.90 & $0 \cdot 01$ \\
\hline Energy & $0.94^{\mathrm{a}}$ & $0 \cdot 82^{\mathrm{b}}$ & 0.88 & 0.88 & 0.01 \\
\hline
\end{tabular}

RMSE, root mean square error.

a,b Mean values within a row within a treatment with different superscript letters were significantly different $(P<0.05)$.

* For details of diets and procedures, see Table 1 and pp. 366-367.

pigs fed on the low fibre diet $(0 \cdot 106 \mathrm{~g} / \mathrm{kg})$. Carbohydrates, particularly NSP, were the dominant constituents of ileal DM effluent with $93 \mathrm{~g} / \mathrm{d}$ in the low-fibre diet $v .559 \mathrm{~g} / \mathrm{d}$ in the high-fibre diet.

Starch and most of the NSP were broken down in the hind-gut with only 40 and $140 \mathrm{~g} \mathrm{NSP} / \mathrm{d}$ being recovered in faecal material from the low- and high-fibre diets 
Table 4. Digestibility of polysaccharides at the terminal ileum and at faeces level in pigs fed on low- or high-fibre diets*

(Mean values for four pigs)

\begin{tabular}{|c|c|c|c|c|c|c|}
\hline \multirow[b]{2}{*}{ Dietary fibre... } & \multicolumn{3}{|c|}{ Ileal digestibility } & \multicolumn{3}{|c|}{ Faecal digestibility } \\
\hline & Low & High & RMSE & Low & High & RMSE \\
\hline \multicolumn{7}{|l|}{ Ileal digestibilities } \\
\hline Arabinose & -0.19 & $0 \cdot 11$ & 0.43 & $0.59^{\mathrm{a}}$ & $0.93^{\mathrm{b}}$ & 0.09 \\
\hline Xylose & -0.29 & -0.15 & $0 \cdot 22$ & $0 \cdot 44$ & 0.50 & 0.08 \\
\hline Mannose & $0.31^{a}$ & $-0.42^{b}$ & 0.16 & $0.84^{a}$ & $0.58^{\mathrm{b}}$ & 0.06 \\
\hline Galactose & $-0.41^{2}$ & $0 \cdot 15^{\mathrm{b}}$ & $0 \cdot 27$ & $0 \cdot 51^{\mathrm{a}}$ & $0.84^{\mathrm{b}}$ & $0 \cdot 10$ \\
\hline Glucose & $0.34^{a}$ & $-0.09^{h}$ & $0 \cdot 19$ & 0.65 & 0.67 & 0.09 \\
\hline Uronic acids & $-0 \cdot 12$ & -0.68 & 0.69 & $0 \cdot 33^{a}$ & $0.94^{b}$ & 0.26 \\
\hline
\end{tabular}

RMSE, root mean square error.

a.b Mean values within a row within a treatment with different superscript letters were significantly different $(P<0.05)$

* For details of diets and procedures, see Table 1 and pp. $366-368$.

Table 5. Daily flow of wet materials, dry matter, nutrients and organic acids at ileal and faecal levels in pigs fed on low-or high-fibre diets*

(Mean values for four pigs)

\begin{tabular}{|c|c|c|c|c|c|c|c|c|c|}
\hline \multirow[b]{2}{*}{ Dietary fibre... } & \multicolumn{3}{|c|}{ Ileal } & \multicolumn{3}{|c|}{ Faecal } & \multicolumn{3}{|c|}{$\begin{array}{c}\text { Disappearance in } \\
\text { hind-gut }\end{array}$} \\
\hline & Low & High & RMSE & Low & High & RMSE & Low & High & RMSE \\
\hline Diet $(\mathrm{kg} / \mathrm{d})$ & $2 \cdot 26^{a}$ & $2 \cdot 59^{b}$ & 0.01 & & & & & & \\
\hline $\begin{array}{l}\text { Wet wt }(\mathrm{kg} / \mathrm{d}) \\
\text { DM }(\mathrm{g} / \mathrm{kg} w \mathrm{t})\end{array}$ & $\begin{array}{l}2 \cdot 80^{\mathrm{a}} \\
0 \cdot 106^{\mathrm{a}}\end{array}$ & $\begin{array}{l}15 \cdot 30^{\mathrm{b}} \\
0.072^{\mathrm{b}}\end{array}$ & $\begin{array}{l}0.40 \\
0.01\end{array}$ & $\begin{array}{l}0.30^{\mathrm{a}} \\
0.508^{\mathrm{a}}\end{array}$ & $\begin{array}{l}1.27^{\mathrm{b}} \\
0.297^{\mathrm{b}}\end{array}$ & $\begin{array}{l}0.20 \\
0.03\end{array}$ & $2 \cdot 50^{\mathrm{a}}$ & $14 \cdot 30^{\mathrm{b}}$ & 0.24 \\
\hline Dry wt $(\mathrm{g} / \mathrm{d})$ & $270^{\mathrm{a}}$ & $1073^{\mathrm{b}}$ & 26 & $146^{\mathrm{a}}$ & $378^{\mathrm{b}}$ & 39 & $124^{\mathrm{a}}$ & $695^{b}$ & 34 \\
\hline $\begin{array}{l}\text { Organic matter } \\
(\mathrm{g} / \mathrm{d})\end{array}$ & $206^{\mathrm{a}}$ & $906^{b}$ & 23 & $97^{\mathrm{a}}$ & $334^{b}$ & 23 & $110^{\mathrm{a}}$ & $571^{\mathrm{b}}$ & 26 \\
\hline Protein $(g / d)$ & $69^{\mathrm{a}}$ & $133^{\mathrm{h}}$ & 5 & $24^{\mathrm{a}}$ & $99^{b}$ & 9 & 44 & 34 & 11 \\
\hline Starch $(\mathrm{g} / \mathrm{d})$ & $5^{a}$ & $49^{1)}$ & 1 & 0 & 0 & - & $5^{\mathrm{a}}$ & $49^{\mathrm{b}}$ & 1 \\
\hline $\operatorname{NSP}(g / d)$ & $93^{\mathrm{a}}$ & $559^{\mathrm{b}}$ & 17 & $40^{\mathrm{a}}$ & $140^{\mathrm{b}}$ & 7 & $52^{a}$ & $419^{h}$ & 11 \\
\hline $\begin{array}{r}\text { Lactic acid } \\
(\mathrm{mmol} / \mathrm{d})\end{array}$ & $94 \cdot 3$ & $394 \cdot 7$ & $185 \cdot 6$ & $0 \cdot 1^{a}$ & $52 \cdot 0^{\mathrm{b}}$ & $14 \cdot 8$ & $94 \cdot 5$ & $342 \cdot 7$ & $171 \cdot 2$ \\
\hline $\begin{array}{l}\text { Acetic acid } \\
(\mathrm{mmol} / \mathrm{d})\end{array}$ & $92 \cdot 1^{2}$ & $204 \cdot 0^{\mathrm{b}}$ & $19 \cdot 7$ & $16 \cdot 2^{a}$ & $137 \cdot 4^{b}$ & $29 \cdot 4$ & $75 \cdot 8$ & 66.5 & $45 \cdot 3$ \\
\hline $\begin{array}{l}\text { Propionic acid } \\
(\mathrm{mmol} / \mathrm{d})\end{array}$ & 0.4 & $0 \cdot 4$ & $0 \cdot 2$ & $3 \cdot 4^{\mathrm{a}}$ & $40 \cdot 1^{b}$ & $11 \cdot 3$ & $-3 \cdot 1^{2}$ & $-39 \cdot 7^{b}$ & $11-2$ \\
\hline $\begin{array}{l}\text { Butyric acid } \\
(\mathrm{mmol} / \mathrm{d})\end{array}$ & $6 \cdot 6$ & $8 \cdot 5$ & 1.9 & $0.2^{\mathrm{a}}$ & $18 \cdot 5^{\mathrm{b}}$ & 6.9 & $6 \cdot 3^{a}$ & $-10 \cdot 0^{b}$ & $8 \cdot 4$ \\
\hline $\begin{array}{l}\text { Isobutyric acid } \\
(\mathrm{mmol} / \mathrm{d})\end{array}$ & $0 \cdot 3$ & $0 \cdot 3$ & 0.1 & $0.7^{\mathrm{a}}$ & $3 \cdot 9^{b}$ & $0 \cdot 8$ & $-0.4^{\mathrm{a}}$ & $-3 \cdot 6^{b}$ & $0 \cdot 8$ \\
\hline $\begin{array}{l}\text { Isovaleric acid } \\
(\mathrm{mmol} / \mathrm{d})\end{array}$ & $0 \cdot 6$ & $0 \cdot 4$ & $0 \cdot 1$ & $1 \cdot 4^{a}$ & $5 \cdot 3^{\mathrm{b}}$ & $1 \cdot 1$ & $-0.8^{a}$ & $-4 \cdot 9^{b}$ & $1 \cdot 1$ \\
\hline $\begin{array}{l}\text { Total SCFA } \\
(\mathrm{mmol} / \mathrm{d})\end{array}$ & $100 \cdot 5^{\mathrm{a}}$ & $214 \cdot 6^{b}$ & $21 \cdot 3$ & $22 \cdot 4^{a}$ & $211 \cdot 3^{b}$ & $50 \cdot 8$ & $78 \cdot 1$ & $3 \cdot 3$ & $68 \cdot 1$ \\
\hline
\end{tabular}

RMSE, root mean square error; SCFA, short-chain fatty acids.

a.b Mean values within a row within a treatment with different superscript letters were significantly different $(P<0.05)$.

* For details of diets and procedures, see Table 1 and pp. 366-368. 
Table 6. The influence of dietary fibre $(F)$ and environmental temperature $(T)$ on energy utilization in pigs $\dagger$

(Mean values for four pigs)

\begin{tabular}{|c|c|c|c|c|c|c|c|c|}
\hline \multirow{2}{*}{$\begin{array}{l}\text { Dietary fibre... } \\
\text { Temperature... }\end{array}$} & \multicolumn{2}{|c|}{ Low } & \multicolumn{2}{|c|}{ High } & \multirow[b]{2}{*}{ RMSE } & \multicolumn{3}{|c|}{ Significance } \\
\hline & $13^{\circ}$ & $23^{\circ}$ & $13^{\circ}$ & $23^{\circ}$ & & $\mathbf{F}$ & $\mathbf{T}$ & $\mathbf{F} \times \mathbf{T}$ \\
\hline GE intake $(\mathrm{MJ} / \mathrm{d})$ & $38 \cdot 05$ & 38.05 & 44.08 & $44 \cdot 44$ & $0 \cdot 24$ & $* * *$ & NS & NS \\
\hline $\mathrm{DE}$ intake (MJ/d) & $35 \cdot 82$ & $35 \cdot 77$ & 36.05 & 36.45 & $0 \cdot 37$ & NS & NS & NS \\
\hline $\mathrm{ME}$ intake $(\mathrm{MJ} / \mathrm{d})$ & $34 \cdot 88$ & 34.93 & $34 \cdot 64$ & $35 \cdot 14$ & 0.27 & NS & NS & NS \\
\hline \multicolumn{9}{|l|}{ Energy $\%$ of DE as } \\
\hline Urine & $2 \cdot 4$ & $2 \cdot 1$ & $2 \cdot 7$ & $2 \cdot 3$ & $0 \cdot 36$ & NS & NS & NS \\
\hline $\mathrm{CH}_{4}$ & 0.2 & $0 \cdot 2$ & $1 \cdot 1$ & $1 \cdot 3$ & 0.03 & $* *$ & NS & NS \\
\hline $\mathrm{ME}$ & $97 \cdot 4$ & $97 \cdot 6$ & $96 \cdot 1$ & $96 \cdot 4$ & $0 \cdot 38$ & $* *$ & NS & NS \\
\hline \multicolumn{9}{|c|}{ Energy disappearance ( $\%$ of GE) } \\
\hline Ileum & $92 \cdot 6$ & $94 \cdot 4$ & $70 \cdot 1$ & $72 \cdot 6$ & $1 \cdot 35$ & *** & NS & NS \\
\hline Hind-gut & $7 \cdot 4$ & $5 \cdot 6$ & $29 \cdot 9$ & $27 \cdot 3$ & 1.35 & $* * *$ & NS & NS \\
\hline \multicolumn{9}{|l|}{ DE values (MJ/kg DM) } \\
\hline Ileal & $16 \cdot 21$ & $16 \cdot 50$ & $10 \cdot 86$ & 11.27 & $0 \cdot 17$ & $* * *$ & $*$ & NS \\
\hline Hind-gut & $1 \cdot 30$ & 0.99 & 4.63 & $4 \cdot 27$ & $0 \cdot 24$ & $* * *$ & NS & NS \\
\hline Faecal & $17 \cdot 51$ & $17 \cdot 49$ & $15 \cdot 49$ & $15 \cdot 54$ & $0 \cdot 20$ & $* * *$ & NS & NS \\
\hline $\mathrm{ME}(\mathrm{MJ} / \mathrm{kg} \mathrm{DM})$ & $17 \cdot 05$ & $17 \cdot 07$ & 14.89 & 14.98 & $0 \cdot 16$ & $* * *$ & NS & NS \\
\hline \multicolumn{9}{|l|}{ Utilization of $\mathrm{ME}$} \\
\hline HP (MJ/kg DM) & $10 \cdot 41$ & 8.99 & $10 \cdot 04$ & $8 \cdot 73$ & $0 \cdot 29$ & NS & $* *$ & NS \\
\hline $\mathrm{RE}(\mathrm{MJ} / \mathrm{kg} \mathrm{DM})$ & 6.64 & $8 \cdot 09$ & 4.84 & $6 \cdot 25$ & $0 \cdot 38$ & $* *$ & $* *$ & NS \\
\hline $\mathrm{HP} / \mathrm{ME}(\%)$ & $61 \cdot 1$ & 52.6 & $67 \cdot 4$ & $58 \cdot 3$ & $2 \cdot 2$ & $*$ & $* *$ & NS \\
\hline $\mathrm{RE} / \mathrm{ME}(\%)$ & 38.9 & $47 \cdot 4$ & $32 \cdot 5$ & $41 \cdot 7$ & $2 \cdot 2$ & $*$ & $* *$ & NS \\
\hline RE-fat/RE (\%) & 77 & 75 & 69 & 74 & $1 \cdot 1$ & $* *$ & NS & $*$ \\
\hline RE-protein/RE (\%) & 23 & 25 & 31 & 26 & $1 \cdot 1$ & $* *$ & NS & $*$ \\
\hline
\end{tabular}

RMSE, root mean square error; GE, gross energy; DE, digestible energy; ME, metabolizable energy; HP, heat production; RE, retained energy; RE-fat, retained energy in fat; RE-protein, retained energy in protein.

Mean values were significantly different: ${ }^{*} P<0.05,{ }^{* *} P<0 \cdot 01, * * * P<0-001$.

$\uparrow$ For details of diets and procedures, see Table 1 and pp. 366-368.

respectively. Hence net disappearance of carbohydrates in the hind-gut was highly correlated with DF intake, but the net disappearance of protein ( 44 and $34 \mathrm{~g} / \mathrm{d}$ for low- and high-fibre diets) was independent of DF level.

The daily flows of organic acids (lactic acid (LA) + SCFA) in ileal digesta were 194.8 and $609.3 \mathrm{mmol} / \mathrm{d}$ with LA:SCFA ratios of 0.94 and 1.84 for the low- and high-fibre diets respectively. LA was the dominant organic acid in ileal digesta, while the dominant organic acids in faecal material were acetic acid $(70.7$ and $65.3 \%)$ and propionic acid $(15.0$ and $18.6 \%$ of SCFA). Organic acids excreted in faeces were $12-43 \%$ of the organic acids passing the ileum with SCFA accounting for more than $80 \%$ of the total organic acids. The high DF intake caused an increase in faecal bulk from 0.30 (low fibre) to $1.27 \mathrm{~kg} / \mathrm{d}$ and in faecal DM from 146 to $378 \mathrm{~g} / \mathrm{d}$.

\section{Energy metabolism}

There was no significant difference in ME intake between the two diets (Table 6). Energy loss as $\mathrm{CH}_{4}$ in pigs on the high-fibre diet was $1.2 \%$ but for those fed on the low-fibre diet it was only $0.2 \%$ of DE. Pigs given the low-fibre diet digested a higher proportion of energy in the small intestine (ileal: $93.5 \%$; hind-gut: $6.5 \%$ ) than pigs on the high-fibre diet (ileal: 
$71 \cdot 4 \%$; hind-gut: $28 \cdot 6 \%$ ). Approximately the same amount of energy was dissipated as heat per $\mathrm{kg} \mathrm{DM}$ from the low- and high-fibre diets ( 9.70 and $9.39 \mathrm{MJ} / \mathrm{kg} \mathrm{DM})$. However, as $\mathrm{ME} / \mathrm{kg} \mathrm{DM}$ in the high-fibre diet was $2.13 \mathrm{MJ}$ lower than in the low-fibre diet, heat production as a proportion of $\mathrm{ME}$ increased from 0.57 to 0.63 . Consequently, retained energy decreased from $0 \cdot 43$ to $0 \cdot 37$.

The environment temperature did not influence the site of energy absorption (small intestine or hind-gut) but there was a high impact on heat production which increased from $19.44 \mathrm{MJ} / \mathrm{d}$ at $23^{\circ}$ to $22.34 \mathrm{MJ} / \mathrm{d}$ at $13^{\circ}$ thus leaving less energy available for retention. Pigs kept at the low temperature retained $35.7 \% \mathrm{ME}$ while pigs kept at $23^{\circ}$ retained $44.6 \% \mathrm{ME}$. Expressed per $\mathrm{kg} \mathrm{DM}$ the decreases in retained energy from $23^{\circ}$ to $13^{\circ}$ environment were 1.45 and $1.41 \mathrm{MJ} / \mathrm{kg} \mathrm{DM}$ for the low- and high-fibre diets respectively. This difference was not significant. The relative proportion of energy retained as protein was higher in pigs fed on the high-fibre diet than in pigs fed on the low-fibre diet. This was particularly the case for pigs kept at $13^{\circ}$ with protein retention enhanced in relation to fat retention.

\section{DISCUSSION}

\section{Body weight and length and weight of gastrointestinal tract}

All pigs in the present study were slaughtered $4 \mathrm{~h}$ after the morning meal. The high DF level increased the amount of digesta in the digestive tract (gutfill) nearly threefold compared with the low fibre level (Table 2). This increase is of the same magnitude as shown with other fibre sources (Just, 1982; Just et al. 1983a) and demonstrates that gutfill can account for a significant part of live weight depending on diet composition. As discussed by Just (1982), this increase in gutfill, and hence live weight, caused by feeding a fibrous diet will at least partly cancel the influence of fibre on energy utilization when expressed relative to body weight. When expressing heat production in relation to metabolic body weight ( $\left.\mathrm{W}^{0.75}\right)$ the difference between the low- and high-fibre diets was $3.7 \%(773.9$ and $802.4 \mathrm{~kJ} / \mathrm{d}$ per $\mathrm{kg} \mathrm{W}^{0.75}$ ) whereas when correcting for gutfill and using empty metabolic body weight the difference increased to $8 \cdot 1 \%\left(791.0\right.$ and $855 \cdot 4 \mathrm{~kJ} / \mathrm{d}$ per $\left.\mathrm{kg} \mathrm{EBW}{ }^{0.75}\right)$.

Measurements in the present study confirmed that intake of high-fibre diets causes a significant extension of the GI tract with an increased length as well. A similar hypertrophy of gut tissues after consuming fibrous diets has been confirmed in rat studies (Goodlad \& Mathers, 1990; Hansen et al. 1992; Zhao et al. 1995). These changes will have an impact on energy metabolism as visceral organs have a high rate of energy expenditure relative to their size (Ferrell \& Koong, 1986; Pekas \& Wray, 1991). In studies with growing pigs Yen et al. (1989) found that hepatic-portal-vein-drained organs including the GI tract used a disproportionately high amount $(25 \%)$ of whole-body maintenance expressed as $\mathrm{O}_{2}$ consumption, although they only represent a small proportion $(5 \%)$ of the body weight.

\section{Digestibility}

There was a difference of $209 \mathrm{~g} \mathrm{DF} / \mathrm{kg}$ DM between the two types of diet (low fibre: $60 \mathrm{v}$. high fibre: $269 \mathrm{~g} \mathrm{DF} / \mathrm{kg} \mathrm{DM})$. The reduced energy digestibility $(0 \cdot 29)$ of the high-fibre diet compared with the low-fibre diet (low fibre: $0.87 v$. high fibre: 0.58 ) can mainly be attributed to the differences in DF levels even though there were differences between the two diets in protein and starch content due to the experimental design. A negative correlation between DF and digestibility of protein, DM and energy is well established in pigs and rats (Eggum et al. 1982, 1984; Just et al. 1983a, b). Hansen et al. (1992) compared different sources of DF and found that the decrease in apparent energy digestibility was more pronounced for wheat bran and oat bran than for pea fibre as used in the present study. The effect of DF on nutrient digestibility may partly be explained by an increased 
rate of passage through the digestive tract as demonstrated in pigs (Varel et al. 1988) and rats (Hansen et al. 1992). Transit time also depends on the length of the entire gut, especially the length of caecum-colon. Our measurements showed an increased length of the large intestine of pigs fed with the high-fibre diet (Table 2). This might partly compensate for the effect of fibre on the rate of passage. DF has also been found to cause increased mucus secretion in the digestive tract. This could, as discussed by Satchithanandam et al. (1990), result in more rapid transit and impaired nutrient absorption. Digestibility of other dietary constituents is certainly influenced by the fibres in the cell walls that might hinder the access of digestive enzymes to the cell contents (Bach Knudsen et al. 1993). Furthermore, peas as well as fibre from peas are known to contain antinutritional factors which depress digestibility (Liener, 1989).

Contamination with endogenous and microbial matter could contribute to the polysaccharide content of the digesta and lead to an underestimation of fibre digestion. This could explain some of the negative digestibilities found for the polysaccharide constituents (Table 4). Similar findings have been found and discussed by Graham et al. (1986) when feeding wheat bran and sugarbeet pulp to pigs. The general pattern of degradation of NSP constituent sugars in the high-fibre diet (arabinose $>$ galactose $>$ glucose $>$ mannose $>$ xylose) was similar to that found by Graham \& Åman (1987) in a study with whole-crop peas. However, in the present study the uronic acid constituent in the high-fibre diet was highly degradable. Approximately half of the uronic acid in the highfibre diet originated from the pectin, which is found to be highly degradable (Livesey et al. 1995).

The low ambient temperature caused a marginal reduction in digestibilities at the ileal level; this effect was significant for starch (Table 3). This agrees with results reported in other studies with pigs (Fuller \& Boyne, 1972; Phillips et al. 1982; Le Dividich \& Noblet, 1986). As indicated by Christopherson \& Kennedy (1983) the thermal environment affects the rate of passage of digesta with a lower retention time in the digestive tract at lower temperatures, allowing less time for microbial fermentation in the hind-gut leading to a lower digestibility. Therefore it was expected to have a higher influence on digestibility from the fibrous diet but we did not observe any difference between diets at the faecal level. On the other hand the pigs kept in the cold environments developed a significantly longer small intestine (Table 2). Similar observations have been made in rats kept in similar environments (Zhao et al. 1995). This might have an effect on the nutrients digested by endogenously secreted enzymes.

\section{Flow of nutrients at terminal ileum and faeces levels}

The importance of diet composition for the degree of fermentation in the hind-gut is clearly demonstrated by the results for the quantitative flow of nutrients through the terminal ileum and net disappearance of nutrients in the hind-gut (Table 5). The amount of digesta flow at the terminal ileum was five- to sixfold higher in pigs fed on the high-fibre diet compared with pigs fed on the low-fibre diet, demonstrating the water-holding capacity of the fibre used. Degradation of $75 \%$ of the NSP in the hind-gut is accompanied by absorption of water and minerals, especially $\mathrm{Na}$ (Jørgensen et al. 1985). The net disappearance of carbohydrates in the hind-gut was positively related to DF intake, while the disappearance of protein was independent of DF intake in agreement with other studies (Graham et al. 1986; Bach Knudsen et al. 1993). This shows that carbohydrates are the most important fuel for the microflora in the hind-gut. The caecum and the proximal and ascending colon of pigs have been shown to be the most important sites of the hind-gut for microbial fermentation of carbohydrates with more than $92 \%$ of the carbohydrates being fermented within these segments (Bach Knudsen et al. 1993). Fermentation in the hind-gut 
yields SCFA as the major energy-containing end-product. When energy is limiting in the hind-gut the C-skeletons from deamination of amino acids are used as an energy source for the microflora. Branched-chain fatty acids are thus derived from breakdown of branched-chain amino acids (Macfarlane et al. 1986). With the low-fibre diet somewhat less starch was available for fermentation and more protein disappeared than with the highfibre diet in the hind-gut. In the faecal content of pigs fed on the low-fibre diet there were also higher proportions of isobutyric and isovaleric acids (0-038v. 0.069) than in faecal content from pigs fed on the high-fibre diet $(0.019 v .0 .026)$.

SCFA are rapidly absorbed from the gut lumen (Argenzio \& Southworth, 1974; Rechkemmer et al. 1988). The net disappearance of carbohydrates together with the theoretical production of SCFA given by Miller \& Wolin (1979) indicates that the production of SCFA within the hind-gut might have reached approximately $580 \mathrm{mmol} / \mathrm{d}$ in pigs fed on the low-fibre diet and as high as $4800 \mathrm{mmol} / \mathrm{d}$ for those fed on the high-fibre diet.

\section{Energy metabolism}

Feeding the high-fibre diet caused an additional energy loss in the form of $\mathrm{CH}_{4}$ of $1 \%$ of DE compared with feeding the low-fibre diet (Table 6), as observed by other researchers (Christensen \& Thorbek, 1987; Noblet et al. 1994). Apart from $\mathbf{C H}_{4}$ the microbial fermentation also yields $\mathrm{H}_{2}$, which is normally considered to be of minor importance in total energy metabolism. However, in vitro measurements of $\mathrm{CH}_{4}$ and $\mathrm{H}_{2}$ production on identical diets to those used in the present study have shown that the highest concentration and the highest production rates of $\mathrm{H}_{2}$ were found in the last third of the small intestine in contrast to $\mathrm{CH}_{4}$ which was produced in the last part of the hind-gut (Jensen \& Jørgensen, 1994). In this study the in vitro $\mathrm{H}_{2}$ production from pigs fed on the high-fibre diet was on average $40 \%$ of $\mathrm{CH}_{4}$ production, showing that $\mathrm{H}_{2}$ excretion has to be taken into consideration when measuring energy metabolism.

When relating energy expenditure to experimental treatments it is common to normalize to metabolic body size or lean body mass. By doing so the treatment effect might be blurred because variation in energy expenditure has been attributed to variations in chemical composition of the total body or composition of gain (Ferrell et al. 1979; Jørgensen et al. 1990). The influence of DF intake on the amount of gutfill clearly demonstrates the weakness of using metabolic body size when comparing energy utilization in the whole animal. Therefore in the present experiment, when feeding the same daily amount of $\mathrm{ME}$, it was chosen to express energy utilization per $\mathrm{kg} \mathrm{DM}$ or relative to ME intake.

As in other studies (Just et al. 1983 a; Hoffmann et al. 1990; Shi \& Noblet, 1993; Bakker et al. 1994) an increasing proportion of DE in the present study was digested in the hindgut when DF level was increased. This value represented $6.5 \% \mathrm{DE}$ for the low-fibre diet and $28.6 \%$ DE for the high-fibre diet. When relating the fermentation in the hind-gut to the utilization of $\mathrm{ME}$ for energy retention (retained energy/ME\%) it was estimated that there was a reduction of 0.27 units for each additional unit of DE digested at the hind-gut level. This is equivalent to a utilization of $73 \%$ of energy derived from hind-gut fermentation in comparison with energy enzymically digested in the small intestine. This value is within the range found by Hoffmann et al. (1990) (66\%), Noblet et al. (1994) (81\%) and Bakker et al. (1994) (63\%). However, it is much higher than that obtained by Just et al. $(1983 a)(51 \%)$ who varied the energy derived from hind-gut fermentation from 18 to $33 \%$ using increasing amounts of cellulose and potato starch in the diet.

The higher heat production and consequently lower retained energy in proportion to the supplied amount of ME with increased fibre level is expected (e.g. Just et al. $1983 \mathrm{~b}$; Noblet et al. 1985; Bakker et al. 1994). The increased heat production is associated with additional 
energy costs of ingestion and digestion. Furthermore, fermentation of the large amount of organic matter from the high-fibre diet ( $571 \mathrm{~g}$ organic matter/d) compared with the lowfibre diet $(110 \mathrm{~g}$ organic matter/d) contributed to the increased heat production.

Energy expenditure as heat in a cold environment could be used to meet the elevated maintenance needs. In other words, the heat generated from nutrient digestion and metabolism could play a useful role in a cold environment by reducing the amount of nutrients or body tissue being oxidized for heat production (Noblet et al. 1985). The present results indicate a stronger negative influence of fibre on energy retention at $23^{\circ}$ than at $13^{\circ}$, although this was not significant. In spite of no significant interactions in overall energy utilization, energy retained as fat or protein was significantly different between the two diets at different temperatures. Thus, the results indicate than when feeding a high-fibre diet to pigs at the same level of ME as a low-fibre diet, energy from produced SCFA will primarily be deposited as body fat.

It can be calculated from the data in Table 6 that heat production was increased by $290 \mathrm{~kJ} /$ pig per $\mathrm{d}$ for each $1^{\circ}$ reduction in the ambient temperature, which is in the range reported by other researchers (Verstegen et al. 1973; Close \& Mount, 1978; Noblet et al. 1985). However, it is likely that the critical temperature for the pigs in the present study was well below $23^{\circ}$. Furthermore, there is experimental evidence (Close \& Mount, 1978) suggesting that the rate of increase in heat production is slower at temperatures just below the critical temperature. Based on this experience it is probably unwise to talk in terms of increases in heat production per $1^{\circ}$ fall in temperature.

\section{CONCLUSION}

Per kg EBW the GI tract of pigs fed on the high-fibre diet was significantly heavier than the GI tract from the pigs fed on the low-fibre diet. Low environmental temperature also caused a heavier GI tract compared with that in pigs kept at higher environmental temperatures. The present study also demonstrates that DF has a low energy density due to a low digestibility and a low net energy value of the absorbed nutrients from fibre. The estimate showed that the utilization of retained energy/ME for energy derived from fermentation in the hind-gut was $73 \%$ of the energy value enzymically digested in the small intestine. The increased heat production of $290 \mathrm{~kJ} / \mathrm{pig}$ per $\mathrm{d}$ for each $1^{\circ}$ reduction in ambient temperature from $23^{\circ}$ to $13^{\circ}$ corresponds to $20 \mathrm{~g}$ from the low-fibre diet and $23 \mathrm{~g}$ from the high-fibre diet.

This work was supported by the Danish Agricultural and Veterinary Research Council. The authors would like to thank Knud Erik Bach Knudsen for carrying out the fibre analyses, Peter Theil and Benny Thomasen for excellent technical assistance and Karl Henrick Jakobsen and Peter Sørensen for their qualified care of the animals.

\section{REFEREN CES}

Anugwa, F. O. I., Varel, V. H., Dickson, J. S. \& Pond, W. G. (1989). Effects of dietary fiber and protein concentration on growth, feed efficiency, visceral organ weights and large intestine microbial populations of swine. Journal of Nutrition 119, 879-886.

Argenzio, R. A. \& Southworth, M. (1974). Sites of organic acid production and absorption in the gastrointestinal tract of the pig. American Journal of Physiology 228, 454-460.

Association of Official Analytical Chemists (1975). Official Methods of Analysis, 11th ed. Washington, DC: Association of Official Analytical Chemists.

Bach Knudsen, K. E., Jensen, B. B., Andersen, J. O. \& Hansen, I. (1991). Gastrointestinal implications in pigs of wheat and oat fractions. 2. Microbial activity in the gastrointestinal tract. British Journal of Nutrition 65 , 233-248.

Bach Knudsen, K. E., Jensen, B. B. \& Hansen, I. (1993). Digestion of polysaccharides and other major components in the small and large intestine of pigs fed on diets consisting of oat fractions rich in $\beta$-D-glucan. British Journal of Nutrition 70, 537-556. 
Bakker, G. C. M., Dekker, R. A., Jongbloed, R. \& Jongbloed, A. W. (1994). The effect of starch, fat and nonstarch polysaccharides on net energy and on the proportion of digestible organic matter or digestible energy that disappeared in the hindgut. In Energy Metabolism of Farm Animals. EAAP Publication no, 76, pp. 163-166 [J. F. Aguilera, editor]. Madrid: CSIC Publishing Service.

Brouwer, E. (1965). Report of Sub-committee on Constants and Factors. In Energy Metabolism. EAAP Publication no. 11, pp. 441-443 [K. L. Blaxter, editor]. London: Academic Press.

Christensen, K., Chwalibog, A., Henckel, S. \& Thorbek, G. (1988). Heat production in growing pigs calculated according to the RQ and $\mathrm{CN}$ methods. Comparative Biochemistry and Physiology 91A, 463-468.

Christensen, K. \& Thorbek, G. (1987). Methane excretion in the growing pig. British Journal of Nutrition 57, 355-361.

Christopherson, R. J. \& Kennedy, P. M. (1983). Effect of thermal environment on digestion in ruminants. Canadian Journal of Animal Science 63, 477-496.

Close, W. H. (1989). The influence of the thermal environment on the voluntary food intake of pigs. In The Voluntary Food Intake of Pigs. British Society of Animal Production Occasional Publication no. 13, pp. 87-97 [J. M. Forbes, M. A. Varley and T. L. J. Lawrence, editors]. Midlothian, Scotland: BSAP.

Close, W. H. \& Mount, L. E. (1978). The effects of plane of nutrition and environmental temperature on the energy metabolism of the growing pig. 1. Heat loss and critical temperature. British Journal of Nutrition 40, 413-421.

Dauncey, M. J. \& Ingram, D. L. (1986). Acclimatization to warm or cold temperatures and the role of food intake. Journal of Thermal Biology 11, 89-93.

Eggum, B. O., Beames, R. M., Wolstrup, J. \& Bach Knudsen, K. E. (1984). The effect of protein quality and fibre level in the diet and microbial activity in the digestive tract on protein utilization and energy digestibility in rats. British Journal of Nutrition 51, 305-314.

Eggum, B. O., Thorbek, G., Beames, R. M., Chwalibog, A. \& Henckel, S. (1982). Influence of diet and microbial activity in the digestive tract on digestibility, and nitrogen and energy metabolism in rats and pigs. British Journal of Nutrition 48, 161-175.

Englyst, H. N., Wiggins, H. S. \& Cummings, J. H. (1982). Determination of non-starch polysaccharides in plant foods by gas-liquid chromatography of constituent sugars as alditol acetates. Analyst 107, 307-318.

Ferrell, C. L., Crouse, J. D., Field, R. A. \& Chant, J. L. (1979). Effects of sex, diet and stage of growth upon energy utilization by lambs. Journal of Animal Science 49, 790-801.

Ferrell, C. L. \& Koong, K. J. (1986). Influence of plane of nutrition on body composition, organ size and energy utilization of Sprague-Dawley rats. Journal of Nutrition 116, 2525-2535.

Fuller, M. F. \& Boyne, A. W. (1972). The effects of environmental temperature on the growth and metabolism of pigs given different amounts of food. 2. Energy metabolism. British Journal of Nutrition 28, 373-384.

Fussell, R. J. \& McCalley, D. V. (1987). Determination of volatile fatty acids $\left(\mathrm{C}_{2}-\mathrm{C}_{5}\right)$ and lactic acid in silage by gas chromatography. Analyst 112, 1213-1216.

Goodlad, J. S. \& Mathers, J. C. (1990). Large bowel fermentation in rats given diets containing raw peas (Pisum sativum). British Journal of Nutrition 64, 569-587.

Graham, H. \& Åman, P. (1987). Whole-crop peas. II. Digestion of early- and late-harvested crops in the gastrointestinal tract of pigs. Animal Feed Science and Technology 17, 33-43.

Graham, H., Hesselman, K. \& Åman, P. (1986). The influence of wheat bran and sugar-beet pulp on digestibility of dietary components in a cereal-based pig diet. Journal of Nutrition 116, 242-251.

Hansen, I., Bach Knudsen, K. E. \& Eggum, B. O. (1992). Gastrointestinal implications in the rat of wheat bran, oat bran and pea fibre. British Journal of Nutrition 68, 451-462.

Hoffmann, L., Jentsch, W. \& Schiemann, R. (1990). Energieumsatzmessungen am adulten Schwein bei Verfütterung von Rationen mit Kartoffelstärke, Kartoffeln, Rüben, Pressschnitzeln und Grobfuttermitteln als Zulagen zu einer Grundration. 1. Energieumsatz und Energieverwertung (Measuring of the energy metabolism of adult pigs after feeding of rations with potato starch, potatoes, beets, sugar beet pulp and roughage as supplements to a basic ration. 1. Energy metabolism and energy utilization). Archives of Animal Nutrition 40 , 191-207.

Hoffmann, L., Klein, M. \& Schiemann, R. (1991). Energieumsatz wachsender Ratten in Abhängigkeit von der Umgebungstemperatur (Energy metabolism of growing rats in dependence on environmental temperature). Archives of Animal Nutrition 41, 29-47.

Jensen, B. B. \& Jørgensen, H. (1994). Effect of dietary fiber on microbial activity and microbial gas production in various regions of the gastrointestinal tract of pigs. Applied and Environmental Microbiology 60, 1897-1904.

Just, A. (1982). The net energy value of balanced diets for growing pigs. Livestock Production Science 8, 541-555.

Just, A., Fernández, J. A. \& Jørgensen, H. (1983a). The net energy value of diets for growth in pigs in relation to the fermentative processes in the digestive tract and the site of absorption of the nutrients. Livestock Production Science 10, 171-186.

Just, A., Jørgensen, H. \& Fernández, J. A. (1983b). Maintenance requirement and the net energy value of different diets for growth in pigs. Livestock Production Science 10, 487-506.

Jørgensen, H., Just, A. \& Fernández, J. A. (1985). The influence of dietary supply of minerals on apparent absorption and retention of minerals in growing pigs. In Digestive Physiology in Growing Pigs. National Institute of Animal Science Report no. 580, pp. 360-363 [A. Just, H. Jørgensen and J. A. Fernández, editors]. Copenhagen: National Institute of Animal Science. 
Jørgensen, H., Sørensen, P. \& Eggum, B. O. (1990). Protein and energy metabolism in broiler chickens selected for either body weight gain or feed efficiency. British Poultry Science 31, 517-525.

Koong, L. J., Ferrell, C. L. \& Nienaber, J. A. (1985). Assessment of interrelationships among levels of intake and production, organ size and fasting heat production in growing animals. Journal of Nutrition 115, $1383-1390$.

Le Dividich, J. \& Noblet, J. (1986). Effect of dietary energy level on the performance of individually housed earlyweaned piglets in relation to environmental temperature. Livestock Production Science 14, 255-263.

Liener, I. E. (1989). Antinutritional factors in legume seeds: state of the art. In Recent Advances of Research in Antinutritional Factors in Legume Seeds, pp. 6-13 [J. Huisman, T. F. B. van der Poel and I. E. Liener, editors]. Wageningen: Pudoc.

Livesey, G. (1992). The energy values of dietary fibre and sugar alcohols for man. Nutrition Research Reviews $\mathbf{5}$, 61-84.

Livesey, G., Smith, T., Eggum, B. O., Tetens, I. H., Nyman, M., Roberfroid, M., Delzenne, N., Schweizer, T. F. \& Decombaz, J. (1995). Determination of digestible energy values and fermentabilities of dietary fibre supplements: a European interlaboratory study in vivo. British Journal of Nutrition 74, 289-302.

Macfarlane, G. T., Cummings, J. H. \& Allison, C. (1986). Protein degradation by human intestinal bacteria. Journal of General Microbiology 132, 1647-1656.

Miller, T. L. \& Wolin, M. J. (1979). Fermentations by saccharolytic intestinal bacteria. American Journal of Clinical Nutrition 32, 164-172.

Milliken, G. A. \& Johnson, D. E. (1984). Analysis of Messy Data. Vol. 1. Designed Experiments. New York: Van Nostrand Reinhold Company.

Neergaard, L., Petersen, C. B. \& Thorbek, G. (1969). Carbon determination in biological materials related to respiration trials. Zeitschrift für Tierphysiologie, Tierernährung und Futtermittelkunde 25, 302-308.

Noblet, J., Fortune, H., Shi, X. S. \& Dubois, S. (1994). Prediction of net energy value of feeds for growing pigs Journal of Animal Science 72, $344-354$.

Noblet, J., Le Dividich, J. \& Bikawa, T. (1985). Interaction between energy level in the diet and environmental temperature on the utilization of energy in growing pigs. Journal of Animal Science 61, 452-459.

Pekas, J. C. \& Wray, J. E. (1991). Principal gastrointestinal variables associated with metabolic heat production in pigs: statistical cluster analyses. Journal of Nutrition 121, 231-239.

Phillips, P. A., Young, B. A. \& McQuitty, J. B. (1982). Liveweight, protein deposition and digestibility responses in growing pigs exposed to low temperature. Canadian Journal of Animal Science 62, 95-108.

Pond, W. G., Jung, H. G. \& Varel, V. H. (1988). Effect of dietary fiber on young adult genetically lean, obese and contemporary pigs: body weight, carcass measurements, organ weights and digesta content. Journal of Animal Science 66, 699-706.

Rechkemmer, G., Rönnau, K. \& Engelhardt, W. v. (1988). Fermentation of polysaccharides and absorption of short chain fatty acids in the mammalian hindgut. Comparative Biochemistry and Physiology 90A, 563-568.

Satchithanandam, S., Vargofcak-Apker, M., Calvert, R. J., Leeds, A. R. \& Cassidy, M. M. (1990). Alteration of gastrointestinal mucin by fiber feeding in rats. Journal of Nutrition 120, 1179-1184.

Schürch, A. F., Lloyd, L. E. \& Crampton, E. W. (1950). The use of chromic oxide as an index for determining the digestibility of a diet. Journal of Nutrition 50, 628-636.

Shi, X. S. \& Noblet, J. (1993). Contribution of the hindgut to digestion of diets in growing pigs and adult sows: effect of diet composition. Livestock Production Science 34, 237-252.

Stahly, T.S. \& Cromwell, G. L. (1986). Responses to dietary additions of fiber (alfalfa meal) in growing pigs housed in a cold, warm or hot thermal environment. Journal of Animal Science 63, 1870-1876.

Statistical Analysis Systems (1985). User's Guide. Statistics. Cary NC: Statistical Analysis Systems Institute, Inc.

Stoldt, W. (1952). Vorslag zur Vereinheitlichung der Fettbestimmung in Lebensmitteln (Suggestions to standardize the determinations of fat in foodstuffs). Fette, Seifen, Anstrichmittel 54, 206-207.

Theander, O. \& Åman, P. (1979). Studies on dietary fibre. 1. Analysis and chemical characterization of watersoluble and water-insoluble dietary fibres. Swedish Journal of Agricultural Research 9, 97-106.

Theander, O. \& Westerlund, E. A. (1986). Studies on dietary fiber. 3. Improved procedures for analysis of dietary fiber. Journal of Agricultural and Food Chemistry 34, 330-336.

Varel, V. H., Jung, H. G. \& Pond, W. G. (1988). Effects of dietary fiber on young adult genetically lean, obese and contemporary pigs: rate of passage, digestibility and microbiological data. Journal of Animal Science 66, $707-712$.

Verstegen, M. W. A., Close, W. H., Start, I. B. \& Mount, L. E. (1973). The effects of environmental temperature and plane of nutrition on heat loss, energy retention and deposition of protein and fat in groups of growing pigs. British Journal of Nutrition 30, 21-35.

Yen, J. T., Nienaber, J. A., Hill, D. A. \& Pond, W. G. (1989). Oxygen consumption by portal vein-drained organs and by whole animal in conscious growing swine. Proceedings of the Society for Experimental Biology and Medicine 190, 393-398.

Zhao, X., Jørgensen, H. \& Eggum, B. O. (1995). The influence of dietary fibre on body composition, visceral organ weight, digestibility and energy balance in rats housed in different thermal environments. British Journal of Nutrition 73, 687-699. 